\title{
Examination of brains of AIDS cases for human immunodeficiency virus and human cytomegalovirus nucleic acids
}

\author{
D G WALKER, * S ITAGAKI, * K BERRY,† P L MCGEER* \\ From the Kinsmen Laboratory of Neurological Research, Department of Psychiatry, ${ }^{*}$ and Department of \\ Pathology, Vancouver General Hospital, $\uparrow$ University of British Columbia, Vancouver, BC, Canada
}

SUMMARY The role of direct virus infection as a determining factor in acquired immunodeficiency syndrome (AIDS) dementia was investigated using in situ hybridisation for human immunodeficiency virus (HIV) and human cytomegalovirus (HCMV). Four of the five AIDS dementia patients in this series demonstrated HIV infected cells distributed in widely different parts of the brain, but only one case showed HCMV infected cells. The greater adundance of HIV was in subcortical white matter in nodular areas consisting of monocyte/macrophage infiltrates. The cells were occasionally arranged as a multinucleated syncitium. In two cases, a few large cells with the appearance of neurons were positive for HIV hybridisation. By appropriate treatment with ribonuclease, it was shown that hybridisation was primarily to HIV RNA. HCMV infected cells were observed in small numbers in only one of the positive cases, suggesting that HCMV is not a determining factor in AIDS dementia. HCMV positive cells were located in the grey matter, with an appearance suggestive of neurons. Cells expressing the MHC-class II antigen HLA-DR, a marker of reactive microglia and macrophages, were observed to be extensive in affected brain sections in the one case examined. These cells were present in greater number than HIV infected cells. In this case, extensive numbers of HIV infected cells were noticed along the peripheral margin of the substantia innominata. This could indicate infection in this case of a critical brain region from the cerebrospinal fluid.

Central nervous system abnormalities, both clinical and postmortem pathological, are observed in a large number of cases of acquired immunodeficiency syndrome (AIDS). Several clinical surveys have noted neurological disorders in approximately $40 \%$ of patients antemortem, with $70-80 \%$ of adult AIDS patients showing neuropathological changes at necropsy. ${ }^{1-3}$ These neuropathological changes are often those of a subacute viral encephalitis and include focal grey and white matter gliosis, microglial nodules, occasional multinucleated giant cells and more rarely, foci of necrosis, demyelination, and perivascular inflammation. ${ }^{4-6}$ The neurological disorders range from lethargy, memory loss and social withdrawal in

\footnotetext{
Address for reprint requests: Dr D G Walker, Kinsmen Laboratory of Neurological Research, Department of Psychiatry, University of British Columbia, 2255 Wesbrook Mall, Vancouver, BC, Canada V6T IW5.
}

Received 19 July 1988 and in revised form 25 November 1988. Accepted 28 November 1988 the early stages to global dementia and incapacity in the terminal stages. ${ }^{7}$ Neurological signs may occasionally be the only evidence of the disease. ${ }^{8}$ The aetiology of the central nervous system dysfunction is still unknown. Direct infection of the brain by HIV has been demonstrated by isolation of HIV from cultures of cells taken from a brain biopsy, ${ }^{9}$ by immunocytochemistry, ${ }^{10-12}$ by Southern blot ${ }^{13}$ and in situ hybridisation analysis. ${ }^{12-16}$ These studies have shown that the HIV infected cells are primarily macrophages and are primarily localised in white matter. It has been demonstrated that HIV strains isolated from the brain or CSF have different properties in culture to HIV blood isolates. ${ }^{17} 18$ This suggests the possibility that neurotropic strains of HIV exist. HIV infections are frequently accompanied by other neural infections. Human cytomegalovirus (HCMV) infections were identified in brains of $26 \%$ of one series of AIDS necropsy cases and Toxoplasma gondii in $14 \%$ of these cases. ${ }^{5}$ It has been suggested that one of these opportunistic pathogens, in particular HCMV, may be the 
cause of the neurological complications. ${ }^{19}$

The aim of this study was to investigate possible pathogenic mechanisms involved in AIDS dementia, in particular, to assess whether coinfection by HCMV has a significant role in this condition. Sections from brain regions of patients who had died with AIDS dementia were examined by in situ hybridisation to determine the extent and distribution of infection with HIV and to examine the frequency and abundance of coinfection of HIV infected brain tissue with HCMV. In addition, immunocytochemical analysis of one brain was carried out to examine the extent of inflammatory changes.

\section{Methods}

Patients. Representative blocks of fixed tissue from five patients who had died from acquired immunodeficiency syndrome (AIDS) with dementia were used in this study. The blocks from cases 1-4 were taken from formalin fixed brain and embedded in paraffin according to standard procedures. The brain from case 5 was fixed in $4 \%$ paraformaldehyde and then transferred to a $15 \%$ buffered sucrose solution. Blocks from this brain were sectioned on a freezing microtome. Sections from paraffin embedded blocks of two cases of Alzheimer's disease were used as controls. The following are brief case histories.

Case 1. This 45 year old male homosexual was noted to have episodes of lymphadenopathy and iritis in March 1985. Six months later, he developed disorientation with loss of recent memory. He was admitted to hospital in December 1985 with Pneumocystis carinii pneumonia (PCP). His speech became incoherent. There was loss of consciousness and the patient died one week later. Necropsy was carried out 30 hours after death. He was found to have focal residual PCP and acute early bronchopneumonia.

Case 2. This 45 year old bisexual male had a 15 year history of diabetes. He developed PCP and was diagnosed as having AIDS in May 1985. He developed a subtle deterioration of memory and intellect and, on assessment in November 1985, was found to be slightly disoriented in time with poor ability to calculate and a poor grasp of general events. He developed increasing confusion and disorientation and died suddenly one month later. The general necropsy, performed 35 hours after death, showed PCP.

Case 3. This 40 year old male homosexual had a history of hepatitis B, gonorrhoea, and possible syphilis. He was treated in December 1984 for viral pneumonia, secondary to Pneumocystis carinii infection and was diagnosed as having AIDS. In October 1985, he developed Kaposi's sarcoma lesions and was beginning to show intermittent confusion and disorientation. The dementia progressed and in March 1986, he was admitted to hospital with fever and diarrhoea. He died one month later after having suffered two major convulsions. Necropsy was performed 16 hours after death. It revealed PCP, Kaposi's sarcoma, acute pancreatitis and evidence of HCMV infection in the lungs, adrenals and kidneys.

Case 4. This 41 year old male homosexual presented in September 1985 with increasing fatigue, fever and weight loss. He was found to be HIV positive. In February 1986, he began to complain of difficulty with memory and to exhibit bizarre behaviour with frequent incontinence. This behaviour continued along with physical deterioration. He died in March 1986. Necropsy was carried out 80 hours after death. It revealed evidence of disseminated Mycobacterium avium infection as well as bronchopneumonia.

Case 5. This 46 year old male homosexual was diagnosed as being HIV positive in August 1985. In July 1986, he was discharged from hospital on sulphonamide drugs for control of presumed cerebral toxoplasmosis. CT and MRI scans of the brain were then normal. He developed nausea and vomiting and a subsequent CT scan in November 1986 revealed a cerebellar mass. He underwent deterioration but responded to dexamethasone although cerebellar signs and confusion remained. The patient developed progressive dementia affecting concentration, attention, calculation and memory. He died in February 1987. Necropsy was performed 6 hours after death; the general findings showed a small foci of bronchopneumonia and renal cysts.

Cases 6 and 7. The two Alzheimer's patients used as controls (88 years and 82 years respectively) had long standing dementing illness. Alzheimer's disease was diagnosed postmortem by the presence of large numbers of neurofibrillary tangles and senile plaques in the neocortex and hippocampus, along with reduced cortical choline acetyltransferase specific activity. Necropsy in both cases was conducted 3.5 hours after death.

In situ hybridisation. In situ hybridisation was performed on sections cut from paraffin embedded or frozen tissues, using a modification of the methods described by Brigati $e t$ $a l^{20} \mathrm{Ten} \mu \mathrm{m}$ paraffin sections were mounted on poly-D-lysine coated slides and heated overnight at $56^{\circ} \mathrm{C}$ to attach the sections to slides. Sections were deparaffinised in three changes of xylene, air dried and rehydrated through graded ethanol $(100 \%, 95 \%, 80 \%, 60 \%, 30 \%)$ to distilled water. Slides were then treated successively with $0.02 \mathrm{M} \mathrm{HCl}(10$ $\mathrm{min}$ ), $0.01 \%$ Triton X-100 (1.5 min), Pronase (Calbiochem, $2 \mathrm{mg} / \mathrm{ml}, 5 \mathrm{~min}$ at room temp) and postfixed with $4 \%$ paraformaldehyde. Sections were rinsed with phosphate buffered saline (PBS) after the $\mathrm{HCl}$ and Triton X-100 steps, and with PBS containing $2 \mathrm{mg} / \mathrm{ml}$ glycine after the pronase and paraformaldehyde steps. Prior to dehydration, sections were acetylated in $25 \mathrm{mM}$ acetic anhydride in $0.1 \mathrm{M}$ triethanolamine (pH 8.0) for $10 \mathrm{~min}$.

Plasmid pARV2 (provided by D. Dina, Chiron Corporation), containing a $9.5 \mathrm{~Kb}$ EcoR 1 insert copy of the AIDSassociated retrovirus (ARV), one of the prototype HIV strains $^{21}$ was used as hybridisation probe to detect HIVinfected cells. Plasmid pCM3, containing EcoR1 fragments A and D of HCMV strain AD169, and plasmid pCM5018, containing EcoR 1 fragment J (HCMV AD 169) (provided by D Galloway, Hutchinson Cancer Centre, Seattle, WA) were used to detect HCMV infected cells. ${ }^{22}$ To prepare DNA for hybridisation probes, plasmid DNA was digested with EcoR1, to release insert DNA from vector DNA. Insert DNA was separated from vector DNA by high performance liquid chromatography on a GF-250 column. ${ }^{23}$ Radioactive hybridisation probes were prepared by labelling DNA fragments with $5^{\prime}\left(\alpha-{ }^{35} \mathrm{~S}\right.$ thio dCTP $(1100 \mathrm{Ci} / \mathrm{mmol}$, New England Nuclear Corp) using random hexamer priming. ${ }^{24}$ Probes with specific activity of $8 \times 10^{8}-10^{9} \mathrm{cpm} / \mu \mathrm{g}$ of DNA were produced. 
Slides were prehybridised for $20 \mathrm{~min}$ at room temperature in prehybridisation solution (consisting of $50 \%$ formamide, $2 \times$ standard saline citrate, $2 \times$ Denhardt's solution, $10 \%$ dextran sulphate, $500 \mu \mathrm{g} / \mathrm{ml}$ denatured salmon sperm), rinsed in $2 \times \mathrm{SSC}$ and then hybridised in hybridisation solution (consisting of prehybridisation solution with the addition of $25 \mathrm{mM}$ dithiothreitol) containing $5 \times 10^{6} \mathrm{cpm} / \mathrm{ml}$ of labelled probe. Sections were coverslipped, sealed with rubber cement, heated to $90^{\circ} \mathrm{C}$ for 7 minutes and then incubated for 18 hours at $37^{\circ} \mathrm{C}$. The sections were subsequently washed in $2 \times$ SSC (10 min, RT), three changes of $2 \times \mathrm{SSC}, 50 \%$ formamide $\left(5 \mathrm{~min}, 37^{\circ} \mathrm{C}\right)$, two changes of $2 \times \operatorname{SSC}(5 \mathrm{~min}$, $\left.37^{\circ} \mathrm{C}\right)$ and two changes of $2 \times \operatorname{SSC}(5 \mathrm{~min}, \mathrm{RT})$. Sections were then dehydrated through graded ethanol (containing $0 \cdot 3 \mathrm{M}$ ammonium acetate) and coated with Kodak NTB-2 film emulsion (diluted $1: 1$ to contain $0.3 \mathrm{M}$ ammonium acetate). Slides were exposed for 1-4 weeks, developed and then counterstained with neutral red. In situ hybridisation was also performed on $30 \mu \mathrm{m}$ sections cut from frozen tissue, after having been processed for immunocytochemistry, by the same procedure with the following modifications. Sections were attached to poly-D-lysine coated slides by immersion in $4 \%$ paraformaldehyde $(5 \mathrm{~min}$ ) and rinsed in PBS. Following hybridisation, sections were washed at each step for twice the period used for paraffin sections.

Immunocytochemistry. Detection of HLA-DR antigen positive cells and HIV antigen positive cells was performed on $30 \mu \mathrm{m}$ free floating sections by previously described methods ${ }^{25}$ using monoclonal antibody HB104 (obtained from the American Type Culture Collection) to HLA-DR, and a rabbit polyclonal antibody to HIV (provided by Dr M V O'Shaughnessy, Bureau of Microbiology, Ottawa, Ont).
When in situ hybridisation was to be performed on sections, the standard diaminobenzidine procedure was used, omitting the nickel ammonium sulphate intensification reaction. In all cases, nearby sections to those used for hybridisation or immunocytochemistry were processed for routine haematoxylin and eosin evaluation.

\section{Results}

Presence of HIV and HCMV infected cells. Extensive examination for virus by in situ hybridisation was made of multiple sections of brains from five AIDS cases with dementia and two Alzheimer disease cases. The brains of four had been fixed for 2 to 3 weeks in $10 \%$ formalin before samples were taken for paraffin embedding. A summary of the results is shown in the table. Positively hybridising cells were readily detectable in a number of samples using the ${ }^{35} \mathrm{~S}$ labelled HIV probe, but not when using a probe against HCMV. This indicated hybridisation was specific to HIV nucleic acid within cells. To determine whether the probe was detecting DNA (proviral or integrated copies of the virus genome) or RNA (virus genomes or messenger RNA), modifications to the hybridisation procedure were carried out on serial sections from the frontal cortex block of case 3. This block was chosen because it was shown to contain large numbers of HIV hybridising cells. Control sections were processed as described in methods, while some were preincubated with $20 \mu \mathrm{g} / \mathrm{ml}$ of RNase A, prior to dehydration, and

Table Summary of clinical, pathological, and in situ hybridisation results

\begin{tabular}{|c|c|c|c|c|c|c|}
\hline Case & Age $(y r) / \operatorname{Sex}$ & $\begin{array}{l}\text { Mental } \\
\text { condition }\end{array}$ & $\begin{array}{l}\text { General } \\
\text { pathology }\end{array}$ & Neuropathology & $\begin{array}{l}\text { Presence of } \\
\text { HIV cells }\end{array}$ & \\
\hline 1 & $45 / M$ & Dementia & HIV, PCP & Mild SE & $\begin{array}{l}\text { Fr. ctx. } \\
\text { Occ. ctx. } \\
\text { Cbm. }\end{array}$ & $\begin{array}{r}++ \\
+ \\
+\end{array}$ \\
\hline 2 & $45 / \mathrm{M}$ & $\begin{array}{l}\text { Disoriented } \\
\text { Confused }\end{array}$ & HIV, PCP & SE & $\begin{array}{l}\text { R. Fr. ctx. } \\
\text { C/P. } \\
\text { L. Thal. } \\
\text { Pons. }\end{array}$ & $\begin{array}{r}+ \\
+ \\
+ \\
-\end{array}$ \\
\hline 3 & $40 / \mathrm{M}$ & Dementia & $\begin{array}{l}\text { HIV, PCP } \\
\text { KS, CMV }\end{array}$ & SE & $\begin{array}{l}\text { Fr. ctx. } \\
\text { R. str. } \\
\text { L. Lent. Nuc. } \\
\text { Medulla } \\
\text { Cbm. }\end{array}$ & $\begin{array}{r}++ \\
++ \\
++ \\
+ \\
+ \\
+\end{array}$ \\
\hline 4 & $41 / \mathrm{M}$ & Dementia & $\begin{array}{l}\text { HIV, Myco. avium } \\
\text { Broncho-pneumonia }\end{array}$ & SE & $\begin{array}{l}\text { Fr. ctx. } \\
\text { Temp. ctx. } \\
\text { Occ. ctx. } \\
\text { L. str. } \\
\text { R. Lent. Nuc. } \\
\text { L. Ant. Thal. }\end{array}$ & $\begin{array}{l}- \\
- \\
- \\
- \\
-\end{array}$ \\
\hline 5 & $46 / \mathrm{M}$ & Dementia & $\begin{array}{l}\text { HIV, Toxo. } \\
\text { Candidiasis }\end{array}$ & SE & $\begin{array}{l}\text { Fr. ctx. } \\
\text { Occ. ctx. } \\
\text { Pons. } \\
\text { Hppc. } \\
\text { Medulla } \\
\text { Sub. Inn. }\end{array}$ & $\begin{array}{r}++ \\
++ \\
+ \\
+ \\
+ \\
+ \\
+\end{array}$ \\
\hline 6 & $88 / \mathrm{M}$ & Dementia & SDAT & $\begin{array}{l}\text { Plaques } \\
\text { Tangles }\end{array}$ & Sub. Inn. & - \\
\hline 7 & $82 / F$ & Dementia & SDAT & $\begin{array}{l}\text { Plaques } \\
\text { Tangles }\end{array}$ & $\begin{array}{l}\text { Temp. ctx. } \\
\text { Sub. Inn. }\end{array}$ & - \\
\hline
\end{tabular}

Abbreviations: HIV, Human immunodeficiency virus infection; PCP, Pneumocystis carinii pneumonia; SE, subacute encephalitis; CMV, human cytomegalovirus infection; KS, Kaposi's sarcoma; Myco. avium, Mycobacterium avium; SDAT, senile dementia of Alzheimer's type. 
in others the DNA in the tissue sections was not heat denatured. Pretreatment with RNase resulted in almost complete loss of hybridisation signal over cells. Omission of heating the sections to $90^{\circ} \mathrm{C}$ resulted in no discernible decrease in signal. This indicated that viral nucleic acids are predominantly RNA and can be detected in specimens even though no special fixation conditions were used for inactivating tissue RNase. It would appear that specimens taken for routine histopathological specimens can be used for hybridisation diagnosis of neural AIDS infections, although there is uncertainty about how much post mortem delay can be tolerated. Sections from blocks taken from the temporal cortex and substantia innominata of two cases of Alzheimer's disease (AD) were also examined as controls. These sections showed evidence of advanced pathology of AD. No cells in these sections gave positive hybridisation with either the HIV or HCMV probes.

Neuropathological examinations: Case 1: Grossly the brain showed only minimal frontal cortical atrophy. Sections through the brain showed mild symmetric dilatation of the lateral ventricles. Microscopic sections through ten randomly selected areas of normal appearing cerebral hemispheres, basal ganglia, brain stem and cerebellum, showed a focus of large cell malignant lymphoma diffusely infiltrating the region of the left ventricular nucleus. There were scattered microglial nodules in deep right frontal white matter, deep occipital white matter, midbrain, pons and inferior olives. There were occasional small foci of sponginess as well as pallor of myelination in the hemispheral white matter, occasionally associated with some axonal spheroid formation. In summary, the patient suffered from malignant lymphoma, coupled with diffuse subacute encephalitis. Hybridisation analysis showed the greatest number of HIV infected cells to be in the frontal cortex white matter. Infected cells were present in microglial nodules that are characteristic of AIDS infection (fig 1). By comparison, the occipital lobe had only sparse numbers of infected cells and the cerebellum none (table).

Case 2: The brain appeared normal on gross examination but coronal slices showed evidence of moderately symmetric dilatation of the lateral ventricles as well as the third ventricle. Sections taken through ten randomly distributed portions of normal appearing cerebral hemispheres, brain stem and cerebellum showed no evidence of subacute encephalitis nor any other recognisable disorder, with the exception of a tiny focus of axonal spheroid formation in the centre of the pons suggesting a so-called focal pontine leucoencephalopathy. Such lesions have previously been reported in AIDS as well as situations involving immunosuppressive treatment. Hybridisation showed this case to have heavy HIV infection of the frontal cortex and less severe infection of the caudate and putamen, with no infection visible in the thalamus and pontine sections.

Case 3: The brain was unremarkable on gross examination. Thirteen randomly selected sections of brain through the cerebral hemisphere, brain stem and cerebellum, showed many microglial nodules. In summary, there was widespread evidence of subacute encephalitis by standard histopathology. This case was of interest because coinfection with HCMV was identified in the brain by hybridisation. A disseminated HIV infection was also demonstrated (table). Infection with HCMV was identified peripherally as well as centrally. The greatest abundance of HIV infected cells was in the frontal cortex, but infection was also found in the cerebellum. In contrast to the other cases, the infected cells were very diffusely distributed throughout the section rather than being clustered in noticeable nodules (fig 2). A section from the medulla of this case also demonstrated occasional cells with the appearance of neurons that hybridised to the HIV probe (fig 3). HCMV infection showed a somewhat different pattern in this single positive case. The most noticeable feature was the sparsity of cells that appeared to be infected. They had the characteristics of small neurons, but only $2-3$ infected cells per section were identified in the frontal cortex, striatum, lenticular nucleus and cerebellum (fig 4). Although it was not possible to observe intranuclear cytomegalic inclusions due to the concentration of silver grains over the positive cells, these inclusions were not observed in other sections of this case. Therefore, the HIV infection did not appear to predispose the patient

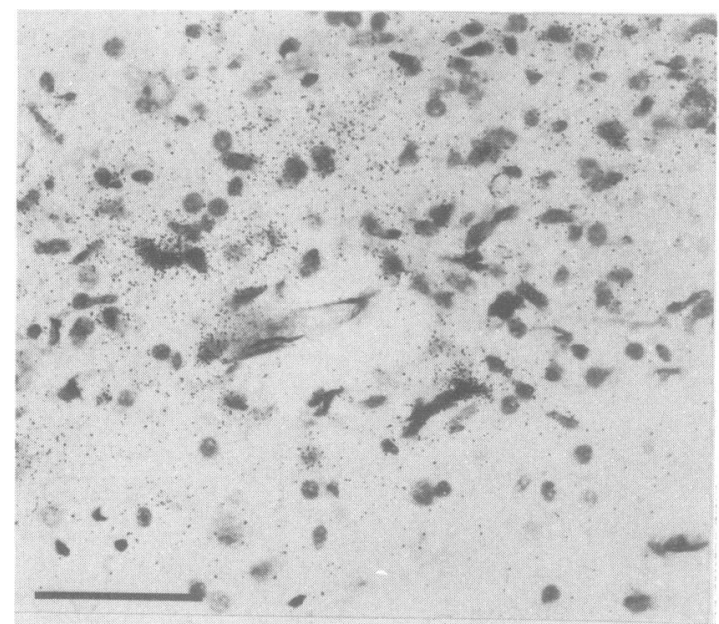

Fig 1 Photomicrograph of focal accumulation of mononuclear cells in white matter area of frontal cortex of case 1. Diffuse clusters of silver grains identify cells showing positive hybridisation to HIV probe. Bar indicates 50 um. 


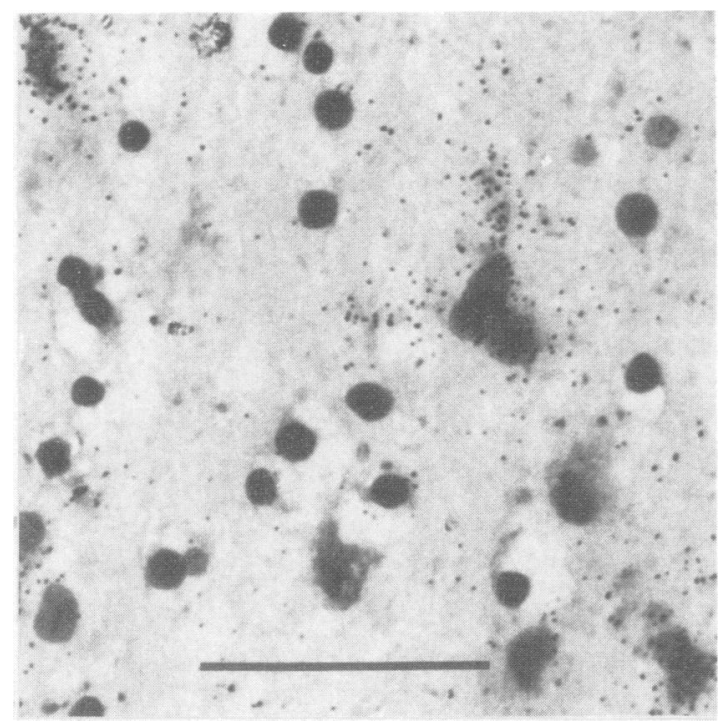

Fig 2 Photomicrograph of HIV nucleic acid containing cells as identified by in situ hybridisation and autoradiography. Cells located in white matter area of frontal cortex of case 3. Note individual arrangement of positive cells in contrast to focal accumulation in fig 1 . Bar indicates $50 \mu \mathrm{m}$.

to a generalised infection by HCMV. It is possible, however, that coinfection with HCMV, which is also known to have immunosuppressive properties,${ }^{26}$ may have predisposed the patient to a more disseminated HIV infection.

Case 4: Grossly, the brain showed moderately severe diffuse cerebral cortical atrophy, and minimal dilata-

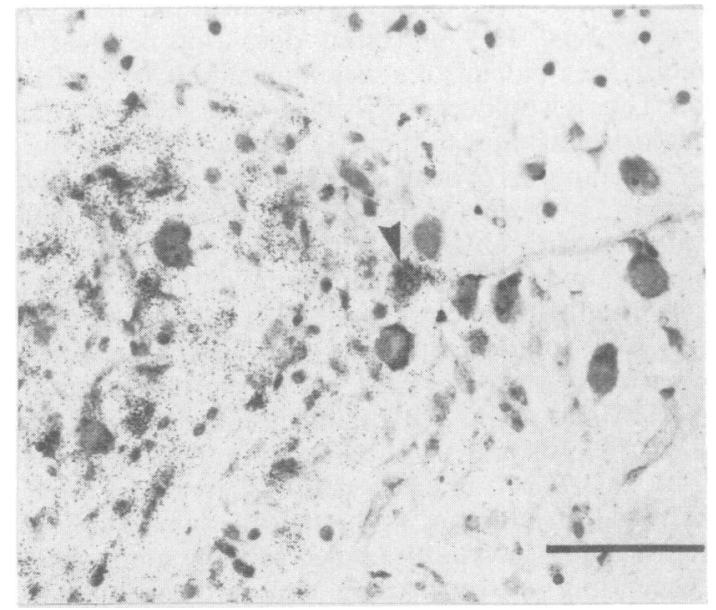

Fig 3 Photomicrograph of HIV nucleic acid containing cells as identified by in situ hybridisation and autoradiography. Section from medulla of case 3. Positively hybridising cell has the appearance of neuron. Bar indicates $50 \mu \mathrm{m}$.

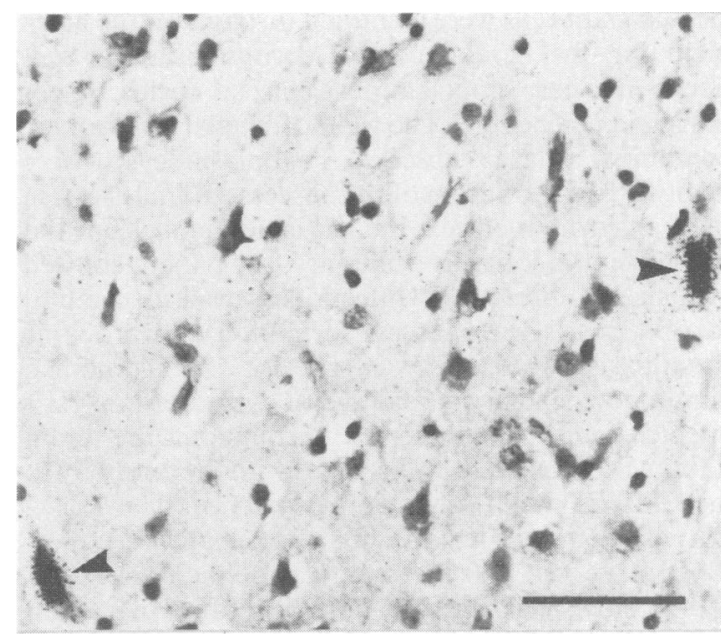

Fig 4 Photomicrograph of HCMV nucleic acid containing cell as identified by in situ hybridisation and autoradiography. Section from frontal cortex of case 3. Positively hybridising cell has appearance of neuron. Bar indicates $50 \mu \mathrm{m}$.

tion of the ventricular system. Microscopic sections through twelve randomly selected sections of cerebral hemispheres, brain stem and cerebellum showed a focus of mononuclear inflammatory cells in the right subfrontal cortex, microglial nodules in the left caudate, but little else of note. The findings were considered to be minimal but supportive of the diagnosis of subacute encephalitis. Surprisingly, even though this case had a clinical history consistent with AIDS related dementia, there was no detectable HIV (or HCMV) infection in the brain regions examined (table). These included the frontal cortex, which had been positive in the other cases examined. Although it is possible that appropriate blocks were not examined, it should be noted that the postmortem delay $(80$ hours) prior to fixation of the brain was much longer than in the other cases. Thus degradation of viral RNA may have occurred.

Case 5: Grossly, the brain appeared to have some congestion of the vessels. Coronal slices through the cerebral hemispheres showed areas of yellowish discolouration in the frontal lobe unilaterally and in the parietal occipital lobes bilaterally. A lesion was also evident grossly in the right upper pontine tegmentum as well as a necrotic area in the deep cerebellar white matter. Eleven sections were taken for microscopic examination, including the necrotic areas. There was evidence of widespread subacute encephalitis characterised by microglial nodule formation and diffuse astrocytosis in the frontal cortex, basal ganglia, hippocampus, thalamus, midbrain and inferior olivary nuclei. Perivascular aggregates of multinu- 
cleated giant cells were identified throughout the brain including the frontal cortex, corpus striatum, lenticular nucleus, hippocampus, parietal cortex, upper pons and cerebellum. The right cerebellar hemisphere contained a large abscess. Toxoplasmocysts were identified at the margin of the abscess and in lesions in the right frontal cortex, the left caudate nucleus, and both occipital lobes. In summary, the patient showed evidence of direct HIV infection as well as cerebral toxoplasmosis with abscess formation and probable candidiasis. Case 5 was studied by combined immunocytochemistry and in situ hybridisation. HIV infected cells were detected throughout the brain (table). Sections were also stained with the antibody to the Class II major histocompatibility antigen HLADR, which detects reactive microglia in brain sections. It was observed that there were also abundant HLADR positive cells throughout the brain. In certain areas, HLA-DR positive cells were positive for virus nucleic acid or were found surrounding virus infected cells (fig 5), while in more extensive areas HLA-DR positive cells were independent of virus infected cells. Immunocytochemical staining of the substantia innominata from this case, using an antibody to HIV, revealed intense staining along one peripheral margin, next to the dura (fig 6a). As a control, an adjacent section was stained with antibody to HLA-DR (fig $6 \mathrm{~b})$. To confirm this observation, adjacent sections were processed for in situ hybridisation. Figure $6 \mathrm{c}$ shows similarly that a number of virus infected cells are present along this margin. The specificity of the hybridisation for HIV was confirmed by the absence of hybridisation with the HCMV probe to another adjacent section (fig 6d).

\section{Discussion}

This study has demonstrated the feasibility of diagnosis of HIV infections in the brain by in situ hybridisation, using the tissues taken for routine histopathological analysis. The distribution and pathological characteristics of infected cells varied from case to case. It was significant that multinucleated giant cells were only rarely observed in sections containing many HIV positive cells. Thus, the presence of such giant cells, while diagnostic for HIV encephalitis, is nevertheless an insensitive criterion for histopathological diagnosis. Histopathological examination by normal staining procedures on several of the sections which contained numbers of HIV nucleic acid containing cells also revealed no obvious abnormalities. In confirmation of other studies, we could not find a clear correlation between the severity of dementia and direct brain infection by HIV and/or HCMV. ${ }^{12}{ }^{16}$ Detailed in situ analysis of brain sections for HCMV infection was performed to supplement

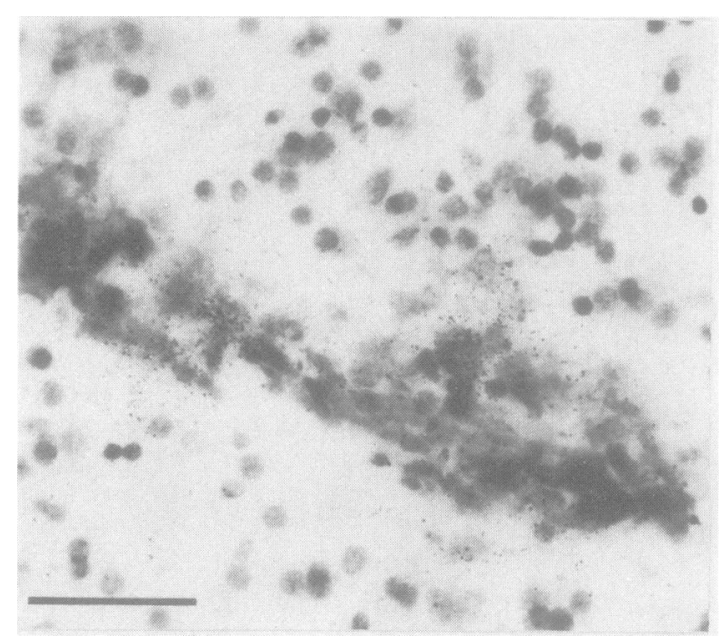

Fig 5 Photomicrograph of section from frontal cortex of case 5 identifying $H L A-D R$ antigen positive cells and HIV nucleic acid containing cells. Note focal accumulation of $H L A-D R$ positive cells colocalise with HIV nucleic acid positive cells. Diffuse grey staining around cells of microglial nodule represents peroxidase substrate product. Bar indicates $50 \mu \mathrm{m}$.

previous observations. ${ }^{127}$ With one exception, previous studies have diagnosed HCMV infections on the basis of histopathology or immunocytochemis try. ${ }^{4-6}$ However, it has been shown that cells with? normal appearance and without detectable HCMV antigen can contain HCMV nucleic acids. ${ }^{27}$ The one positive case for HCMV nucleic acids in this small series of AIDS dementia cases demonstrated that even a widespread HIV infection does not necessarily predispose a patient to a disseminated HCMV infection. Thus it would seem possible to rule out $\mathrm{HCMV}$ as a major contributor to the AIDS dementia syndrome.

The symptoms of dementia nevertheless indicate the existence of a major neuronal dysfunction which would require sizeable numbers of neurons to be compromised directly by infection or indirectly by some reaction that compromised physiological action. It has been observed that some populations of neurons and astrocytes express CD4, the cell surface receptor of HIV, and could potentially become infected by HIV. ${ }^{28}{ }^{29}$ However, as was observed in this study, and by Wiley et al, ${ }^{16}$ infected neurons are only rarely observed. In addition, pathological examination of brain sections have not revealed sizeable numbers of degenerating neurons using standard histopathological techniques. This was confirmed in the cases examined in this study.

Several interesting observations were possible when immunocytochemical staining of brain sections, in 


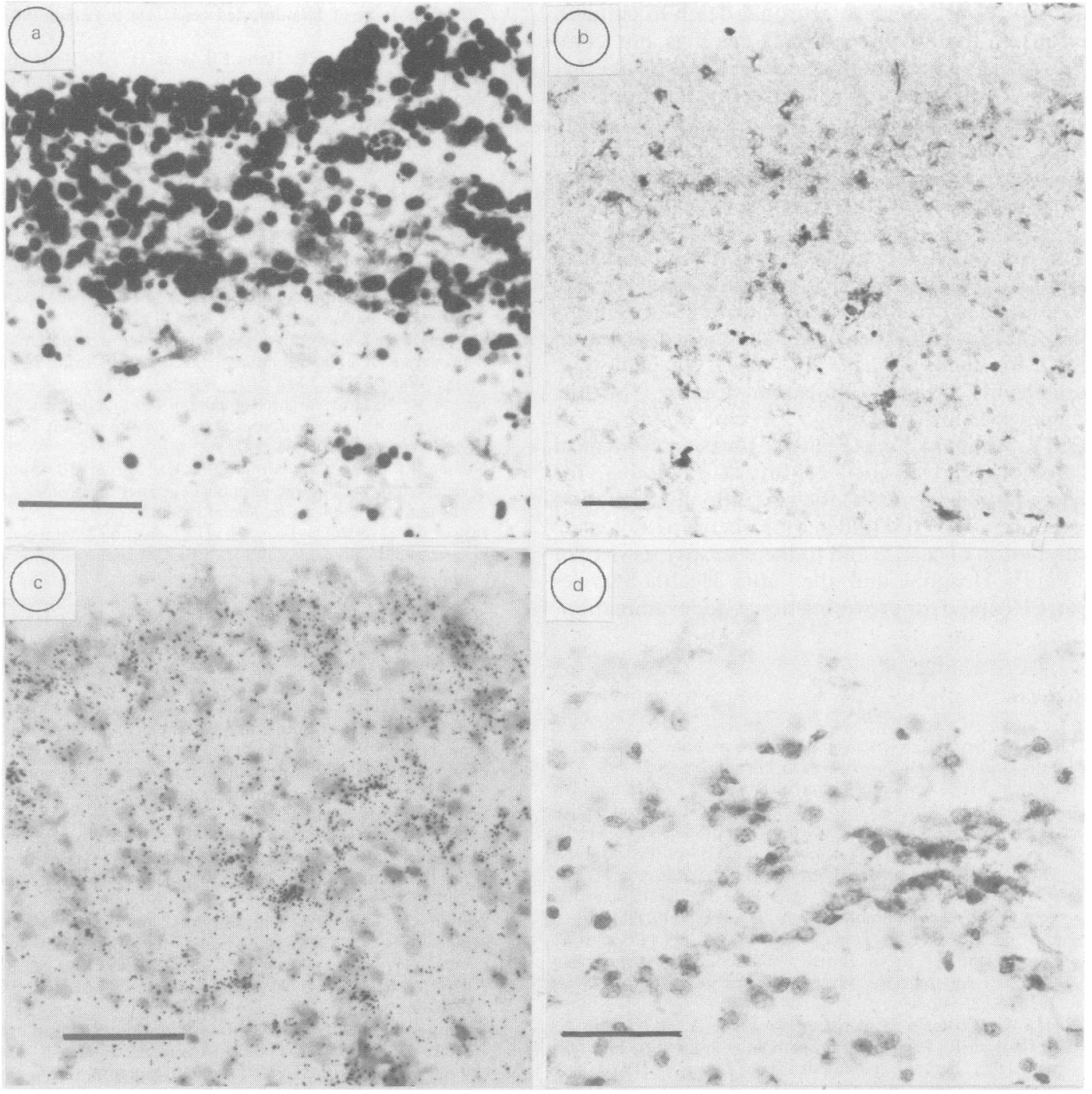

Fig 6 Photomicrographs of sections from the substantia innominata of case 5 identifying HIV positive cells.

(a) Section stained by immunocytochemistry using antibody to HIV. (b) Section stained by immunocytochemistry using antibody to HLA-DR. (c) Section hybridised with HIV probe. (d) Section hybridised with HCMV probe. Note the accumulation of positive cells along the margin of the tissue in both $(a)$ and $(c)$. Bars indicate $50 \mu \mathrm{m}$.

conjunction with in situ hybridisation, was performed. Staining with the antibody to HLA-DR revealed a large number of immunoreactive cells, that are assumed to be reactive microglia. This would seem to indicate the presence of a generalised inflammatory reaction throughout the brain and does not support the observation that HIV brain infections are characterised by a lack of a significant inflammatory response. ${ }^{30}$ The observation of a large number of infected cells on the margin of the substantia innominata in one case may be of significance. This area of the brain has been shown to be severely affected by Alzheimer's disease, which also is characterised by cognitive impairment and dementia. ${ }^{31}$

The aetiology of the dementia is still unknown. Two possible mechanisms have been suggested that do not involve direct neural infection. The surface glycoprotein gp120, which is secreted in large amounts, can bind to the vasoactive intestinal peptide (VIP) receptor on the surface of neurons. This binding 
has been shown to cause neuronal death in cultured neurons. ${ }^{32}{ }^{33}$ Although neuronal death is not commonly observed in brain sections, it is possible that binding to this receptor will cause dysfunction. The other mechanism may be a pathological mechanism caused by the interaction of various lymphokines and cytokines, secreted by activated macrophages/ microglia or infected macrophages, on neurons.

This work was supported by a grant from the British Columbia Medical Services Foundation. We are grateful to Dr D Dina, Chiron Corporation, Emeryville, California for providing the cloned probe of ARV2 for these studies, and to Dr D Galloway, Hutchinson Cancer Research Centre, Seattle, Washington for providing the cloned probes of HCMV. We thank Dr J O'Kusky, Division of Medical Microbiology, Univerity of British Columbia, for advice and help with the in situ hybridisation procedure, Dr J Holden for neuropathological examination of case 5, and to the necropsy services of St Paul's Hospital and the UBC Health Services Centre Hospital for providing tissues for examination.

\section{References}

1 Elder GA, Sever JL. Neurologic disorders associated with AIDS retroviral infection. Rev Infect Dis 1988;10:286-302.

2 Faulstich ME. Acquired immune deficiency syndrome: An overview of central nervous system complications and neuropsychological sequelae. Int J Neuroscience 1986;30:249-54.

3 Perry S, Marotta RF. AIDS dementia: A review of the literature. Alzheimer Disease Assoc Disord 1987;1:221-35.

4 Navia BA, Cho E-S, Petito CK, Price RW. The AIDS dementia complex: II. Neuropathology. Ann Neurol 1986;19:525-35.

5 Petito CK, Cho E-S, Lemann W, Navia BA, Price RW. Neuropathology of acquired immunodeficiency syndrome (AIDS): An autopsy review. J Neuropath Exp Neurol 1986;45:635-46.

6 Budka H, Costanzi G, Cristina S, Lechi A, Parravicini C, Trabattoni R, Vago L. Brain pathology induced by infection with the human immunodeficiency virus (HIV). Acta Neuropathol (Berl) 1987;75:185-98.

7 Navia BA, Jordan BS, Price RW. The AIDS dementia complex: I. Clinical features. Ann Neurol 1986;19:517-24.

8 Navia BA, Price RW. The acquired immunodeficiency syndrome dementia complex as the presenting or sole manifestation of human immunodeficiency virus infection. Arch Neurol 1987;44:65-9.

9 Gartner S, Markovits P, Markovitz DM, Betts RF, Popovic M. Virus isolation from and identification of HTLV-III/LAVproducing cells in brain tissue from a patient with AIDS. JAMA 1986;256:2365-71.

10 Gabuzda DH, Ho DD, de la Monte SM, Hirsch MS, Rota TR, Sobel RA. Immunohistochemical identification of HTLV-III antigen in brains of patients with AIDS. Ann Neurol 1986;20:289-95.

11 Pumarola-Sune T, Navia BA, Cordon-Cardo C, Cho E-S, Price RW. HIV antigen in the brains of patients with the AIDS dementia complex. Ann Neurol 1987;21:490-6.

12 Vazeux R, Brousse N, Jarry A, et al. AIDS subacute encephalitis.
Identification of HIV-infected cells. Am J Pathol 1987;126: 403-10.

13 Shaw GM, Harper ME, Hahn BE, et al. HTLV-III infection in brains of children and adults with AIDS encephalopathy. Science 1985;227:177-82.

14 Stoler MH, Eskin TA, Benn S, Angerer RC, Angerer LM. Human T-cell lymphotropic virus type III infection of the central nervous system. $J A M A$ 1986;256:2360-4.

15 Koenig S, Gendelman HE, Orenstein JM, et al. Detection of AIDS virus in macrophages in brain tissue from AIDS patients with encephalopathy. Science 1986;223:1089-93.

16 Wiley CA, Schrier RD, Nelson JA, Lampert PW, Oldstone MBA. Cellular localization of human immunodeficiency virus infection within the brains of acquired immune deficiency syndrome patients. Proc Natl Acad Sci (USA) 1986;83:7089-93.

17 Cheng-Mayer C, Levy JA. Distinct biological and serological properties of human immunodeficiency virus from the brain. Ann Neurol 1988;23:S58-S61.

18 Anand R. Natural variants of human immunodeficiency virus from patients with neurological disorders do not kill $\mathrm{T}^{+}{ }^{+}$cells. Ann Neurol 1988;23:S66-S70.

19 Nielsen L, Petito CK, Urmacher CD, Posner JB. Subacute encephalitis in acquired immune deficiency syndrome: a postmortem study. Am J Clin Pathol 1984;82:678-82.

20 Brigati DJ, Myerson D, Leary JJ, et al. Detection of viral genomes in cultured cells and paraffin embedded tissue sections using biotin-labeled hybridization probes. Virology 1983;125:32-50.

21 Luciw PA, Potter SJ, Steimer K, Dina D, Levy J. Molecular cloning of AIDS-associated retrovirus. Nature 1984;312:760-3.

22 Ruger R, Bornkamm GW, Fleckenstein B. Human cytomegalovirus DNA sequences with homologies to the cellular genome. J Gen Virol 1984;65:1351-64.

23 Boyes BE, Walker DG, McGeer PL. Separation of large DNAO restriction fragments on a size-exclusion column by a nonidea $b$ mechanism. Anal Biochem 1988;170:127-34.

24 Feinberg AP, Vogelstein B. A technique for radiolabeling DNA restriction endonuclease fragments to high specific activity Anal Biochem 1984;137:266-7.

25 McGeer PL, Itagaki S, Tago H, McGeer EG. Reactive microglia in patients with senile dementia of the Alzheimer type are positive for the histocompatability glycoprotein HLA-DR. Neurosci Lett 1987;79:195-200.

26 Schrier RD, Rice GPA, Oldstone MA. Suppression of natura killer cell activity and $T$ cell proliferation by fresh isolates of human cytomegalovirus. J Infect Dis 1986;153:1084-91.

27 Wiley CA, Schrier RD, Denaro FJ, Nelson JA, Lampert PW, Oldstone MBA. Localization of cytomegalovirus proteins and genome during fulminant central nervous system infection in an AIDS patient. J Neuropathol Exp Neurol 1986;45:127-39.

28 Hill JM, Farrar WL, Pert CB. Autoradiographic localization of T4 antigen, the HIV receptor, in human brain. Int $J$ Neurosc 1987;32:687-93.

29 Funke I, Hahn A, Rieber EP, Weiss E, Riethmuller G. The cellular receptor (CD4) of the human immunodeficiency virus is expressed on neurons and glial cells in human brain. $J$ Exp Med 1987;165:1230-5.

30 Wiley CA. Implications of the neuropathology of HIV encephalitis for the pathogenesis of Alzheimer disease. Alzheimer Disease Assoc Disord 1987;1:236-50.

31 McGeer PL, McGeer EG, Suzuki J, Dolman CE, Nagai T. Aging, Alzheimer's disease and the cholinergic system of the basal forebrain. Neurology 1984;34:741-5.

32 Pert CB, Smith CC, Ruff MR, Hill JM. AIDS and its dementia as a neuropeptide disorder: Role of VIP receptor blockade by human immunodeficiency virus envelope. Ann Neurol 1988;23:S71-S73.

33 Brenneman DE, Pert C, Westbrook G. External envelope protein (gp120) of HIV produces neuronal death in hippocampal cultures. Society for Neuroscience Abstracts 1987;abst 137.1. 